\title{
Women by the woman - Kamala Das
}

\author{
Sofia C. Jose \\ Department of English, Bharathiar University, Coimbatore, India. \\ Received 27 January, 2014; Accepted 5 May, 2014
}

\begin{abstract}
Kamala Suraiya (also known as Kamala Das or Madhavikutty) had made it clear to readers, critics and family that she do not want to be "categorized". Das's poetry have flung open its doors to let in, topics that women had kept decorously out (the boredom of marriage, the thrills of love, the pains of being a woman, of being a writer, the loneliness of being unloved, the joy of being in love)..
\end{abstract}

Key words: Kamala Suraiya, poetry, feminist and woman.

\section{INTRODUCTION}

Kamala Suraiya is the first and the most famous poem in the confessional mode. She begins by self assertion but later she remarks various situations, where she was down trodden. The poet, an individual woman tries to voice a universal womanhood trying to share her experiences, good or bad with all other women. Love and sexuality are the strong component in her search for female identity (Raveedran, 1994).

\section{Women by the woman - Kamala Das}

Kamala Das was an exemplary new woman in many ways. She was bold, uninhibited, full of creative energy that she sustained to the very end as is proven by her last few poems in Closure, and secular enough to try another religion in the last days of life... Her burial in a mosque was a great lesson to those with insular minds.

Malayalam poet and bilingual critic $\mathrm{K}$. Sachidanandan

Writing according to Kamala Das is a sort of spiritual therapy. She says:

"If I had been a loved person. I would not have become a writer. I would have been a happy human being."

Das became the subject of her writing, viewing herself with a persistent lens that saw it all, later putting everything onto the page in confessional bursts of poetry or prose. This allegiance to the moment, the urgent need to capture it in words, often gave her writing a first draft, see-through quality that made critics complain of inconsistency. But Kamala Das did not care what others said, she was willing to be swept away by her writing, without stopping to make formal considerations about the composition or to make it reader friendly. She had to write it all out. Kamala Das lived an intensely uneasy life, and the fact that she neither gassed herself nor jumped off a cliff is proof of the faith she kept in her chosen trade, of her conviction that writing was no charlatan occupation, incapable of giving life. When she poured herself out in poetry, stories and features, Kamala Das was working at life, looking in her own words for 
reminders of the importance of wanting to be, wanting to write, wanting to live and no writer can pay greater tribute to her trade than to acknowledge it as the reason for living. And as her readers, we too are privileged with this tribute.

Das's poetry has been intimately connected to critical perception of her personality and politics; her provocative poetry has seldom produced lukewarm reactions. While reviewers of Das's early poetry have praised its fierce originality, bold images, exploration of female sexuality, and intensely personal voice, they lamented that it lacked attention to structure and craftsmanship. Many critics have analyzed Das as a "confessional" poet, writing in the tradition of Sylvia Plath, Anne Sexton, and Denise Levertov. Kamala Das begins by self-assertion:

I am what I am.

The poetess claims that she is not interested in politics, but claims to know the names of all in power beginning from Nehru. She seems to state that these are involuntarily ingrained in her. By challenging us that she can repeat these as easily as days of the week, or the names of months she echoes that these politicians were caught in a repetitive cycle of time, irrespective of any individuality. They did not define time; rather time defined them. Subsequently, she comes down to her roots. She declares that by default she is an Indian. Other considerations follow this factor. She says that she is 'born in' Malabar; she does not say that she belongs to Malabar. She is far from regional prejudices. She first defines herself in terms of her nationality, and second by her colour:

I am Indian, very brown, born in Malabar,

And she is very proud to exclaim that she is 'very brown'. She goes on to articulate that she speaks in three languages, writes in two and dreams in one; as though dreams require a medium. Kamala Das echoes that the medium is not as significant as is the comfort level that one requires. The essence of one's thinking is the prerequisite to writing. Hence she implores with all"critics, friends, visiting cousins" to leave her alone. Kamala Das reflects the main theme of Girish Karnad's "Broken Images"-the conflict between writing in one's regional language and utilizing a foreign language. The language that she speaks is essentially hers; the primary ideas are not a reflection but an individual impression. It is the distortions and queerness that makes it individual. And it is these imperfections that render it human. It is the language of her expression and emotion as it voices her joys, sorrows and hopes. It comes to her as cawing comes to the crows and roaring to the lions, and is therefore impulsive and instinctive. It is not the deaf, blind speech: though it has its own defects, it cannot be seen as her handicap. It is not unpredictable like the trees on storm or the clouds of rain. Neither does it echo the "incoherent mutterings of the blazing fire." It possesses a coherence of its own: an emotional coherence.

She was child-like or innocent; and she knew she grew up only because according to others her size had grown. The emotional frame of mind was essentially the same. Married at the early age of sixteen, her husband confined her to a single room. She was ashamed of her feminity that came before time, and brought her to this predicament. This explains her claim that she was crushed by the weight of her breast and womb. She tries to overcome it by seeming tomboyish. So she cuts her hair short and adorns boyish clothes. People criticize her and tell her to 'conform' to the various womanly roles. They accuse her of being schizophrenic; and 'a nympho'. They confuse her want of love and attention for insatiable sexual craving.

As the girl seeks fulfillment of her adolescent passion, a young lover is forced upon her to traumatize and coerce the female-body since the same is the site for patriarchy to display its power and authority. When thereafter, she opts for male clothing to hide her femininity, the guardians enforce typical female attire, with warnings to fit into the socially determined attributes of a woman, to become a wife and a mother and get confined to the domestic routine. She is threatened to remain within the four walls of her female space lest she should make herself a psychic or a maniac.

But the poet is an individual woman trying to voice a universal womanhood and trying to share her experiences, good or bad, with all other women. Love and sexuality are a strong component in her search for female identity and the identity consists of polarities.

She explains her encounter with a man. She attributes him with not a proper noun, but a common noun-"every man" to reflect his universality. He defined himself by the "I", the supreme male ego. He is tightly compartmentalized as "the sword in its sheath'. It portrays the power politics of the patriarchal society that we thrive in that is all about control. It is this "I" that stays long away without any restrictions, is free to laugh at his own will, succumbs to a woman only out of lust and later feels ashamed of his own weakness that lets himself lose to a woman. Towards the end of the poem, a role-reversal occurs as this "I" gradually transitions to the poetess herself. She pronounces how this "l" is also sinner and saint", beloved and betrayed. As the role-reversal occurs, the woman too becomes the "I" reaching the pinnacle of self-assertion.

Das once said, "I always wanted love, and if you don't get it within your home, you stray a little"(Warrior interview). Though some might label Das as "a feminist" for her candor in dealing with women's needs and desires, Das "has never tried to identify herself with any particular version of feminist activism". Das' views can be characterized as "a gut response," a reaction that, like 
her poetry, is unfettered by other's notions of right and wrong. Nonetheless, poet Eunice de Souza claims that Das has "mapped out the terrain for post-colonial women in social and linguistic terms". Das has ventured into areas unclaimed by society and provided a point of reference for her colleagues. She has transcended the role of a poet and simply embraced the role of a very honest woman.

\section{Conflict of Interests}

The author have not declared any conflict of interests.

\section{REFERENCE}

Raveedran PP (1994). "Text as History, History as Text: A Reading of Kamala Das' Anamalai Poems." J. Commonw. Literature 29(2):4754

\section{Citations}

Rediif Interview

http://www.rediff.com/news/2000/jul/19inter.htm

The Hindu Condolences

http://www.hindu.com/thehindu/holnus/002200905312123.htm http://www.poemhunter.com/best-poems/kamala-das/an-introduction2/Rediff on the Net. Web. <http://www.rediff.com/style/das.htm>

Ravi Database Consultants. India World Poetry. Web. http://www.indiaworld.co.in/open/rec/poetry/mother1.html

Warrier, Shobha. Interview. Rediff on the Net. Web. http://www.rediff.com/news/1996/3107adas.html 